Universidade Estadual Paulista "Júlio de Mesquita Filho"

Faculdade de Medicina de Botucatu

\title{
AVALIAÇÃO DO POTENCIAL CANCERÍGENO DO DIURON [3-(3,4-DICLOROFENIL)-1,1-DIMETILURÉIA] NO MODELO DE INICIAÇÃO-PROMOÇÃO CUTÂNEA EM CAMUNDONGOS SWISS
}

Bianca Ferrucio

Dissertação apresentada ao Programa de Pós-Graduação em Patologia da Faculdade de Medicina de Botucatu, Universidade Estadual Paulista UNESP, para obtenção do título de Mestre em Patologia.

Botucatu - SP 
Universidade Estadual Paulista "Júlio de Mesquita Filho" Faculdade de Medicina de Botucatu

\section{AVALIAÇÃO DO POTENCIAL CANCERÍGENO DO DIURON [3-(3,4-DICLOROFENIL)-1,1-DIMETILURÉIA] NO MODELO DE INICIAÇÃO-PROMOÇÃO CUTÂNEA EM CAMUNDONGOS SWISS}

Mestranda: Bianca Ferrucio

Orientador: João Lauro Viana de Camargo Co-orientador: Deilson Elgui de Oliveira

Dissertação apresentada ao Programa de Pós-Graduação em Patologia da Faculdade de Medicina de Botucatu, Universidade Estadual Paulista UNESP, para obtenção do título de Mestre em Patologia.

Botucatu - SP 
Dedico este trabalho aos meus pais e maiores fãs, Paulo e Tereza. Com o apoio e a dedicação de vocês, difícil é não progredir! Obrigada por acreditarem em mim.

Amo vocês! 


\section{AGRADECIMENTO ESPECIAL}

Ao meu orientador, João Lauro. Serei para sempre grata pela oportunidade e honra de ser sua orientada. Com certeza sentirei falta de um orientador "Father Figure" no doutorado! 


\section{AGRADECIMENTOS}

Ao meu irmão Bruno Cochoco: irmão mais velho, mais careca, e mais companheiro do mundo!

À minha vó Helena, exemplo de força e vitalidade. Obrigada pelo carinho e por todas as comidas congeladas que eu almocei durante estes 2 anos.

Ao meu vô Alcides, por sua excentricidade e por ainda me surpreender, e minha vó Consuelo (in memorian) por fazer parte das minhas melhores lembranças.

Ao Henrique, meu melhor amigo e melhor namorado, por tudo o que construímos e a tudo que sobrevivemos juntos. Te amo!

Às amigas Paulinha e Lu, porque vocês são meu porto seguro e porque vocês são divertidas.

À Ana Rachel, por tantos momentos bons e especiais que passamos juntas, e à Alice, pela segurança de que posso contar com você, mesmo tão distante.

Ao meu co-orientador Deilson, pela ajuda na elaboração deste projeto.

Aos amigos do TOXICAM: Iza, Mitscheli, Shadia, Marize, Gabrielli, Meri (e Edson), Meire, Tony, João, Alexandre, Paulo, Mara, Ivana e PC, e especialmente à Carla, por tantos conselhos e presentinhos, e à querida "equipe" Ana Paula e Vivi.

À Cris, por todas as impressões, telefonemas, scanners, etc...e pelo seu alto astral constante.

Aos funcionários do Laboratório de Patologia Molecular: Marquinhos, Selene, Fernando e Cris por todas as vezes que me socorreram.

À CAPES e à FAPESP, pelo apoio financeiro, e aos camundongos sacrificados para a realização deste estudo. 


\section{ÍNDICE}

\section{REVISÃO DE LITERATURA}

Carcinogênese cutânea $\quad 9$

Bioensaios para detecção de cancerígenos químicos $\quad 13$

$\begin{array}{ll}\text { O herbicida diuron } & 15\end{array}$

REFERÊNCIAS BIBLIOGRÁFICAS

$\begin{array}{ll}\text { MANUSCRITO } & 24\end{array}$

$\begin{array}{ll}\text { Abstract } & 26\end{array}$

$\begin{array}{ll}\text { Introduction } & 27\end{array}$

Material and methods $\quad 30$

Results 33

$\begin{array}{ll}\text { Discussion } & 35\end{array}$

Aknowledgements 39

References 39

Tables $\quad 44$

$\begin{array}{ll}\text { Figures } & 50\end{array}$

APÊNDICE

Tabelas 


\section{REVISÃO DE LITERATURA}

\section{Carcinogênese cutânea}

De acordo com a Organização Mundial da Saúde, um terço de todos os casos de câncer diagnosticados são de pele, e sua incidência tem aumentado nas últimas décadas. Esta observação evidencia a importância da prevenção do câncer de pele, pela identificação dos agentes causadores e minimizando a exposição aos mesmos. Por outro lado, por serem de fácil acesso, neoplasias cutâneas podem ser detectadas precocemente e curadas com sucesso, permitindo a redução das taxas de morbidade e mortalidade.

Visando entender os mecanismos pelos quais agem os agentes cancerígenos, há décadas que a pele de animais de experimentação tem sido estudada em modelos de carcinogênese química, tendo sido o órgão investigado pioneiramente por Yamagiwa \& Ichikawa em 1915 (Williams, 1999). Em 1947, Berenblum \& Shubik descreveram o atual paradigma da carcinogênese de duas etapas, iniciação e promoção, baseados em estudos sobre a atividade cancerígena da resina do óleo de cróton na pele de camundongos. Atualmente, sabe-se que a carcinogênese cutânea é um processo que evolui em múltiplas etapas, caracterizadas experimentalmente como as de iniciação, promoção e progressão (Slaga et al., 1996). A iniciação requer a lesão do DNA e posterior "fixação" desta alteração por pelo menos um ciclo de proliferação; tem por característica a ausência de limiar-de-dose do cancerígeno químico que a provocou, isto é, mesmo doses mínimas podem provocar a iniciação. Assim, todo iniciador da carcinogênese é um agente genotóxico, embora nem todas as substâncias genotóxicas iniciem o processo de carcinogênese (Pitot III \& Dragan, 2001). Alguns agentes iniciadores podem induzir amplificação gênica ou mutação em ponto, e assim ativam protoncogenes; outros iniciadores, por sua vez, provocam a deleção, e conseqüente inativação de genes supressores tumorais que têm efeito protetor contra expansão clonal 
e mutabilidade, como o TP53 (Frame et al., 1998). O oncogene $H-R A S$ é crítico na carcinogênese cutânea de camundongos, já que sua ativação é suficiente para iniciar células epidérmicas, encontrando-se comumente mutado em papilomas e em carcinomas (Hennings et al., 1993). A promoção, por sua vez, é a etapa em que ocorre a expansão clonal das células iniciadas e, consequentemente, a expressão da alteração do genoma ocorrida na iniciação (DiGiovanni, 1992). O promotor, sendo um agente químico ou físico, geralmente age por estímulo à proliferação celular, e tem por característica a existência de um limiar-de-dose abaixo do qual não exerce efeito tumorigênico. Diferente dos agentes iniciadores, os promotores possuem ação epigenética, i.e., não agridem o DNA. Se a exposição aos promotores for interrompida antes do aparecimento de tumores, as alterações estabelecidas por eles, e.g., hiperplasias, regridem, ou seja, são reversíveis (Yuspa et al., 1976).

Finalmente, na etapa da progressão, as células tumorais adquirem as características básicas da malignidade, como aneuploidia e capacidade de invasão tecidual e de metástases, levando à manifestação clínica da doença (Yuspa et al., 1981). A conversão de papilomas a carcinomas cutâneos (progressão) é um evento que raramente ocorre na ausência de novos estímulos externos. É necessária ao menos uma nova alteração genética no clone das células promovidas, além daquelas ocorridas na iniciação (Boukamp, 2005). A progressão se desenvolve por várias mudanças moleculares. Exemplo disso, a expressão das citoceratinas 1 e 10, presente em pele normal e em papilomas, deixa de ser observada em carcinomas, que apresentam expressão da citoceratina 8, característica que se associa com a aquisição do fenótipo maligno (Abel et al., 2009). Da mesma maneira, enzimas como a telomerase e $\gamma$ glutamiltranspeptidase têm expressão aumentada em carcinomas cutâneos, assim como algumas proteases (estromelisina, uroquinase). Fatores de crescimento também são 
importantes marcadores da progressão, como o TGF- $\beta$, pois sua ausência em papilomas representa alto risco para conversão à malignidade (Hennings et al., 1993).

No processo de carcinogênese, inclusive na pele, são observadas alterações nas vias de sinalização celular, decorrentes de modificação nas funções de enzimas com participação em diferentes pontos da transdução de sinais. Dentre as vias mais estudadas nesse contexto estão as cascatas de MAP (mitogen-activated protein) cinases, a via fosfatidilinositol-3-cinase (PI3K) - Akt (ou proteína cinase B, PKB) e a via de proteínas da família NF-kappaB (El-Abaseri \& Hansen, 2007; Kobielak \& Fuchs, 2006; Wattenberg, 2007).

A via das MAP cinases (MAPK) é basicamente constituída por enzimas que fosforilam e ativam uma enzima cinase subseqüente na cascata. A ativação dessa via pode ser deflagrada por fatores de crescimento, agentes mitógenos, receptores acoplados a proteínas $\mathrm{G}$, estresse e citocinas pró-inflamatórias. No topo da cascata estão as MAP3Ks, enzimas que fosforilam e ativam as MAP2Ks, e estas as MAPKs, que por sua vez ativam fatores de transcrição que regulam a expressão de conjunto heterogêneo de genes, em última análise proporcionando aumento da proliferação celular. Entre as MAP3Ks, destacam-se as MEKK1-4 (MAP and ERK kinase kinase), que atuam junto à porção citoplasmática da membrana celular, e as proteínas das famílias Src e Raf (Avruch, 2007). As cinases da família Src desempenham papel crítico na adesão, invasão, proliferação e sobrevivência celular e angiogênese, e assim podem estar envolvidas em todas as etapas da carcinogênese cutânea (Kim et al., 2009).

A ativação da cinase Raf pela cinase Ras, constitui o primeiro passo da cascata Ras/Raf/ERK1/2, que leva à fosforilação de fatores de crescimento que regulam a proliferação e o crescimento celular, sendo assim um alvo terapêutico importante na inibição da tumorigênese cutânea (Chaudhary et al., 2009). Em estudo recente, foi 
demonstrado que o desenvolvimento e a manutenção de tumores induzidos pela proteína Ras são altamente dependentes da proteína Raf-1, que por sua vez é dispensável para a homeostase epidérmica (Ehrenreiter et al., 2009). Neste mesmo estudo, relatou-se que a presença da cinase Raf-1 foi também necessária para a expressão da proteína Myc. Esta proteína, presente nas camadas basais da epiderme, induz a proliferação e inibe a diferenciação de queratinócitos, e está associada à regulação de células-tronco (Watt, 1998).

A via PI3K-Akt, iniciada pela ativação de receptores com atividade tirosina cinase intrínseca (RTK) e receptores acoplados a proteínas G, requer a ativação do mensageiro secundário fosfatidilinositol-3,4,5-trifosfato (PIP3). Uma das principais consequiências da ativação desta cascata de sinalização é a supressão da apoptose e aumento da síntese protéica, o que pode contribuir para a tumorigênese (Osaki et al.,

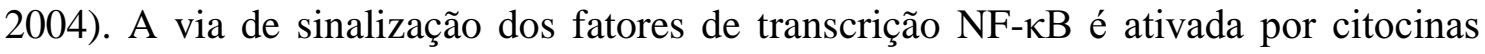
pró-inflamatórias (e.g., TNF, IL1) e por padrões moleculares associados a patógenos, e é dependente da ativação de diversas proteínas cinases, notadamente TAK1 e IKKs. A

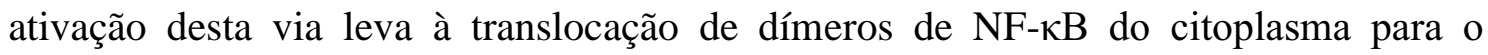
núcleo, sendo essencial na regulação da imunidade inata e da imunidade adaptativa

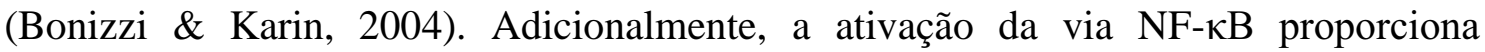
estímulos para aumento da sobrevivência celular (pela diminuição da susceptibilidade à apoptose) e aumento da proliferação. Ativação constitutiva de NF-אB é documentada em diversas neoplasias malignas, incluindo carcinomas em vários sítios anatômicos e neoplasias malignas de origem hematopoiética (Karin, 2006). 


\section{Bioensaios para detecção de cancerígenos químicos}

Existem numerosos protocolos para testar o potencial cancerígeno de substâncias químicas. O ensaio convencional, que tem duração de cerca de dois anos e envolve a administração de altas doses do composto em teste, é muitas vezes inviável devido ao elevado consumo de tempo e de recursos financeiros. Além disso, não considera as múltiplas etapas da carcinogênese química e é pouco eficiente para detectar agentes promotores fracos (Williams, 1999).

Devido a essas limitações, foi realizado considerável esforço para o estabelecimento de testes alternativos para a detecção do potencial cancerígeno de agentes químicos. Os ensaios de carcinogênese de duas etapas apresentam duração mais reduzida (semanas) e consideram também o aparecimento de lesões pré-neoplásicas como desfechos (end-points). Os ensaios de iniciação-promoção podem ser delineados tanto para detectar o potencial promotor de agentes químicos, como o potencial iniciador. No primeiro caso, estes ensaios consistem na indução de células iniciadas pela aplicação de um agente iniciador (mutagênico) e, após certo intervalo, aplicações consecutivas da substância-teste (possível agente promotor), por período prédeterminado; no segundo caso, a substância-teste é administrada previamente ao tratamento com um promotor de tumores conhecido (Tsuda et al., 1999). Assim, este modelo é particularmente importante na investigação do mecanismo de ação de cancerígenos químicos, já que permite a distinção operacional entre as várias etapas do desenvolvimento de tumores (DiGiovanni, 1992).

Na pele de roedores, especialmente a de camundongos, o bioensaio iniciaçãopromoção está bem estabelecido (Abel et al., 2009; Chan et al., 2004; Sancheti \& Goyal, 2006). A hiperplasia e displasia epidérmicas são indicadores precoces da 
atividade cancerígena do composto testado, por serem consideradas precursoras de papilomas e carcinomas de células escamosas (Williams, 1999).

Na mesma linha, foram desenvolvidos bioensaios alternativos de carcinogênese cutânea com animais produzidos por biotecnologia. Tais avanços metodológicos permitem reduzir a duração dos experimentos e o número de animais necessários, além de gerar resultados mais precisos e informações acerca do modo /mecanismo de ação das substâncias testadas (Brown \& Balmain, 1995). Entre os modelos mais utilizados, estão as linhagens Tg.AC e RasH2, que carregam o transgene $H$-RAS ativado. Assim, estes animais são geneticamente iniciados e indicados para a identificação de cancerígenos genotóxicos e não-genotóxicos (Lynch et al., 2007). Na mesma linha, camundongos nocaute Trp53+/- apresentam apenas um alelo funcional do gene supressor tumoral p53 e são altamente suscetíveis ao desenvolvimento de tumores por agentes mutagênicos (French et al., 2001). A linhagem de camundongos SENCAR tem sido utilizada na identificação de agentes iniciadores, promotores e progressores. Embora não seja geneticamente modificada, esta linhagem foi selecionada durante algumas gerações para expressar suscetibilidade elevada à carcinogênese cutânea de duas etapas, apresentando menor período de latência dos tumores (Slaga, 1986).

Em 2003, Pritchard et al. avaliaram a precisão das linhagens transgênicas Trp53+/-, Tg/AC e RasH2 na identificação de cancerígenos humanos, em comparação com os ensaios tradicionais de dois anos. De modo geral, estas linhagens geneticamente modificadas apresentaram boa preditividade, e a combinação de dois modelos diferentes foi considerada a melhor estratégia para avaliar o potencial cancerígeno de substâncias químicas.

Os modelos descritos são considerados ferramenta valiosa na identificação de cancerígenos químicos, principalmente quando a rota de exposição cutânea é a mais 
prevalente em humanos (Enzmann, 1998). Estes ensaios procuram ainda mimetizar a exposição a baixas doses, como tipicamente ocorre na população humana. Além disso, a carcinogênese cutânea em camundongos desenvolve-se de maneira bastante similar àquela em humanos, o que contribui para a justificativa da utilização deste modelo animal. Exemplo disso, a mutação em células tronco epidérmicas é, aparentemente, fator desencadeante da carcinogênese em ambas as espécies (Kangsamaksin et al., 2007). Adicionalmente, muitas das mutações em genes considerados críticos na carcinogênese, como o H-Ras e o Tp53, são comuns tanto em camundongos como em humanos (French et al., 2001; Janowski, 1991). Por outro lado, algumas disparidades dificultam a extrapolação interespécies. Entre elas, está o fato de que camundongos desenvolvem predominantemente papilomas, tumor que não apresenta equivalente humano e que raramente progride a carcinoma de células escamosas, que por sua vez, é o tumor mais frequente na espécie humana (Glick et al., 2007).

\section{O herbicida Diuron}

O diuron (3-(3,4 diclorofenil)-1,1-dimetiluréia) é um herbicida derivado da uréia, amplamente usado no controle de ervas daninhas em campos de cultivo de soja, algodão, cana-de-açúcar, frutas cítricas, trigo e café, assim como em pistas de aeroportos, ferrovias e oleodutos. A exposição ocupacional é a maior preocupação em torno deste herbicida. Trabalhadores agrícolas frequentemente negligenciam práticas de segurança, como o uso de equipamento de proteção individual (EPI) durante a aplicação ou mistura de pesticidas (Carpenter et al., 2002; Perry et al., 2002). Além disso, EPIs podem ser insuficientes para cobrir toda a superfície cutânea e o contato com o exterior contaminado do equipamento é possível (Brower et al., 2005). 
Quando foi submetido ao teste convencional de longa duração em roedores, o Diuron mostrou atividade cancerígena para o urotélio de ratos Wistar e para a mama de camundongos NMRI (Iyer, 2002). Por esta razão, ele é classificado como "provável cancerígeno para a espécie humana" pela Agência de Proteção Ambiental norteamericana (USEPA, 2004). No momento, este herbicida está liberado para uso agrícola em diversos países, inclusive no Brasil, o que não aconteceria se sua atividade mutagênica/cancerígena fosse bem definida (Lei Federal de Agrotóxicos, 1991). É necessário esclarecer qual o modo de ação (MOA) pelo qual o Diuron exerce a atividade cancerígena verificada em roedores e qual seu significado para a espécie humana. Estudos prévios em nosso laboratório demonstraram que o diuron e/ou seus metabólitos induzem tumores na bexiga urinária de ratos Wistar através de citotoxicidade química direta, seguida de proliferação celular regenerativa; no entanto, o mecanismo de ação específico ainda não foi esclarecido (Rocha et al., 2009).

Apesar de ter sido avaliado em vários ensaios in vitro e em ensaios in vivo em mamíferos, a genotoxicidade do Diuron é controversa, dependendo do modelo experimental, dose e parâmetros finais estudados (Grutman et al., 1984; Iyer, 2002; Liu, 2001) (Tabela VII - Apêndice). No ensaio de Ames com Salmonella thyphimurium e ativação metabólica, por exemplo, o Diuron apresentou fraca atividade mutagênica, e no teste do micronúcleo em medula óssea os resultados foram negativos (Seiler, 1978). Em testes in vivo com camundongos Swiss, este herbicida mostrou atividade mutagênica pelo teste de micronúcleo em medula óssea (Agrawal et al., 1996) e pelo teste do dominante letal em células germinativas (Agrawal \& Melhrota, 1997). No entanto, pelo teste Mutatox com uma variante escura (M169) da Photobacterium phosphoreum, os resultados foram inconclusivos (Canna-Michaelidou \& Nicolaou, 1996). A significância biológica de resultados positivos obtidos somente em ensaios citogenéticos tem sido 
questionada, por apresentarem baixa preditividade da carcinogenicidade em roedores (Witte et al., 2007). Além disso, o teste do cometa (ensaio de eletroforese em gel de célula alcalina única) foi sugerido como o método preferível para avaliar a genotoxicidade, uma vez que é relativamente insensível a citotoxicidade; assim, resultados falso-positivos são menos frequentes, mesmo quando altas concentrações do composto teste claramente afetam a viabilidade celular (Witte et al., 2007). Estudos prévios em nosso laboratório indicaram ausência de genotoxicidade do Diuron pelo teste do cometa em células uroteliais e do sangue periférico de ratos Wistar machos (Nascimento et al., 2006). Além disso, uma versão modificada do ensaio desenvolvida in vitro em células $\mathrm{CHO}$ sugeriu que o produto também não é capaz de induzir ligações cruzadas (crosslinks) no DNA (Rocha et al., 2009).

Em 1989, Antony et al. registraram o papel iniciador do Diuron quando aplicado em múltiplas doses sucessivas $(250 \mathrm{mg} / \mathrm{kg}$ p.c., três aplicações/semana, durante 3 semanas), mas não em dose única, em ensaio de iniciação-promoção na pele de camundongos Swiss fêmeas. Como promotor da carcinogênese aqueles autores utilizaram o 12-O-tetradecanoil forbol 13-acetato (TPA), a substância ativa do óleo de cróton. Seus resultados sugeriram que o diuron é uma genotoxina, uma vez que todo agente iniciador é assumidamente genotóxico (Pitot III \& Dragan, 2001). No entanto, Antony et al. (1989) não verificaram potencial iniciador quando o diuron foi aplicado em dose única, o que pode indicar um possível limiar de dose, inconsistente com seu suposto potencial iniciador. Neste caso, influência na promoção da carcinogênese cutânea de camundongos seria mais provável, já que nesta condição um limiar de dose e um MOA não-genotóxico seriam mais apropriados. Antony et al. (1989) não justificaram os níveis de dose adotados para o diuron, o que contribui para a inconsistência daquele estudo. 


\section{REFERÊNCIAS BIBLIOGRÁFICAS}

Abel, E.L., Angel, J.M., Kiguchi, K., DiGiovanni, J. (2009). Multi-stage chemical carcinogenesis in mouse skin: Fundamentals and applications. Nat protoc 4(9), $1350-62$.

Agrawal, R.C., Kumar, S., Mehrotra, N.K. (1996). Micronucleus induction by diuron in mouse bone marrow. Toxicol Lett 89, 1-4.

Agrawal, R.C., Mehrotra, N.K. (1997). Effect of diuron on germ cells of mice. Indian J Exp Biol 35(11), 1256-7.

Antony, M., Shukla, Y., Mehrotra, N.K. (1989). Tumour initiatory activity of a herbicide diuron on mouse skin. Cancer Lett 48, 125-8.

Avruch J. (2007) MAP kinase pathways: The first twenty years. Biochim Biophys Acta 1773(8), 1150-60.

Berenblum, I., Shubik, P. (1947). A new, quantitative approach to the study of the stages of chemical carcinogenesis in the mouse`s skin. Br J Cancer 1,383-91.

Bonizzi, G., Karin, M. (2004). The two NF- $\kappa B$ activation pathways and their role in innate and adaptative immunity. Trends Immunol 25(6), 280-8.

Boukamp, P. (2005). Non-melanoma skin cancer: what drives tumor development and progression? Carcinogenesis 26(10), 1657-67.

Brow, K., Balmain, A. (1995). Transgenic mice and squamous multistage skin carcinogenesis. Cancer Metastasis Rev 14(2), 113-24.

Brouwer, D.H., Aitken, R.J., Oppl, R., Cherrie, J.W. (2005). Concepts of skin protection: considerations for the evaluation and terminology of the performance of skin protective equipment. J Occup Environ Hyg 2(9), 425-34. 
Canna-Michaelidou, S., Nicolaou, A.S. (1996). Evaluation of the genotoxicity potential (by Mutatox ${ }^{\mathrm{TM}}$ test) of ten pesticides found as water pollutants in Cyprus. Sci Total Environ 193, 27-35.

Carpenter, W.S., Lee, B.C., Gunderson, P.D., Stueland, D.T. (2002). Assessment of personal protective equipment use among midwestern farmers. Am J Ind Med 42, 236-47.

Chan, K.S., Sano, S., Kiguchi, K., Anders, J., Komazawa, N., Takeda, J., DiGiovanni, J. (2004) Disruption of Stat3 reveals a critical role in both the initiation and the promotion stages of epithelial carcinogenesis. J Clin Invest 114, 720-8.

Chaudhary, S.C., Alam, M.S., Siddiqui, M.S., Athar, M. (2009). Chemopreventive effect of farnesol on DMBA/TPA-induced skin tumorigenesis: Involvement of inflammation, Ras-ERK pathway and apoptosis. Life Sci 85(5-6), 196-205.

DiGiovanni, J. (1992). Multistage carcinogenesis in mouse skin. Pharmacol Ther 54(1), 63-128.

Ehrenreiter, K., Kern, F., Velamoor, V., Meissl, K., Galabova-Kovacs, G., Sibilia, M., Baccarini, M. (2009). Raf-1 Addiction in Ras-Induced Skin Carcinogenesis. Cancer Cell 16, 149-60.

Enzmann, H., Bomhard, E., Iatropoulos, M., Ahr, H.J., Schlueter, G., Williams, G.M. (1998). Short- and intermediate-term carcinogenicity testing - a review. Part 1: the prototypes mouse skin tumour assay and rat liver focus assay. Food Chem Toxicol 36, 979-95.

El-Abaseri, T.B., Hansen, L.A. (2007). EGFR Activation and Ultraviolet Light-Induced Skin Carcinogenesis. J Biomed Biotechnol 3,1-4.

Frame, S., Crombie, R., Liddell, J., Stuart, D., Linardopoulos, S., Nagase, H., Portella, G., Brown, K., Street, A., Akhurst, R., Balmain, A. (1998). Epithelial 
carcinogenesis in the mouse: correlating the genetics and the biology. Phil Trans $R$ Soc Lond B 353, 839-45.

French, J., Storer, R.D., Donehower, L.A. (2001). The nature of the heterozygous Trp53 knockout model for identication of mutagenic carcinogens. Toxicol Pathol 29, 24-9.

Glick, A.B., Ryscavage, A., Perez-Lorenzo, R., Hennings, H., Yuspa, S., Darwiche, N. (2007). The high-risk benign tumor: evidence from the two-stage skin cancer model and relevance for human cancer. Mol Carcinog 46(8), 605-10.

Grutman, G., Schoofs, L., Lontie, J.F., van Larebeke, N. (1984). The mutagenicity in prokaryotes of herbicides. Residue Rev 91, 1-46.

Hennings, H., Glick, A.B., Greenhalgh, D.A., Morgan, D.L., Strickland, J.E., Tennenbaum, T., Yuspa, S.H. (1993). Critical aspects of initiation, promotion and progression in multistage epidermal carcinogenesis. Soc Exp Biol Med, 202,1-18.

Iyer, P. (2002). Evidence on the development and reproductive toxicity of diuron. Draft. Reproductive and Cancer Hazard Assessment Section. Office of Environmental Health Hazard Assessment, California Environmental Protection Agency, 43.

Janowski, M. (1991) ras proteins and the ras-related signal transduction pathway. Radiat Environ Biophys 30(3), 185-9.

Kangsamaksin, T., Park, H.J., Trempus, C.S., Morris, R.J. (2007). A perspective on murine keratinocyte stem cells as targets of chemically induced skin cancer. Mol Carcinog. 46, 579-584.

Karin, M. (2006). Nuclear factor- $\mathrm{kB}$ in cancer development and progression. Nature 441, 431-6. 
Kim, L.C., Song, L., Haura, E.B. (2009). Src kinases as therapeutic targets for cancer. Nat Rev Clin Oncol 6(10), 587-95.

Kobielak, A., Fuchs, E. (2005). Links between $\alpha$-catenin, NF-кB, and squamous cell carcinoma in skin. PNAS 103(7), 2322-2327.

Liu, J. (2001). Phenylurea herbicides. In Handbook of Pesticide Toxicology - Agents (K.E. Krieger, ed.), Vol. 2, pp. 1521-3. Academic Press, San Diego.

Lynch, D., Svoboda, J., Putta, S., Hofland, H.E.J., Chern, W.H., Hansen, L. (2007) Mouse skin models for carcinogenic hazard identification: utilities and challenges. Toxicol Pathol 35(7), 853-64.

Nascimento, M.G., de Oliveira, M.L.C.S., Lima, A.S., de Camargo, J.L.V. (2006). Effects of diuron [3-(3,4-dichlorophenyl)-1,1-dimethylurea] on the urinary bladder mucosa of male Wistar rats. Toxicology 224, 66-73.

Organização Mundial da Saúde (OMS) - World Health Organization, Health Topics, Skin cancer. http://www.who.int/uv/faq/skincancer/en/index1.html.

Osaki, M., Oshimura, M., Ito, H. (2004) PI3K-Akt pathway: its functions and alterations in human cancer. Apoptosis 9, 667-76.

Perry, M.J., Marbella, A., Layde, P.M. (2002). Compliance with required pesticidespecific protective equipment use. Am J Ind Med 41, 70-3.

Pitot III, H.C., Dragan, Y.P. (2001). Chemical carcinogenesis. In Casarett \& Doull's Toxicology the Basic Science of Poisons (C.D. Klaassen, ed), pp. 241-319. McGraw-Hill, New York.

Pritchard, J.B., French, J.E., Davis, B.J., Haseman, J.K. (2003). The Role of Transgenic Mouse Models in Carcinogen Identification. Environ Health Perspect 111(4), 444-54. 
Rocha, M.S., Nascimento, M.G., Cardoso, A.P.F., Lima, P.L.A., Zelandi, E.A., de Camargo, J.L.V., de Oliveira, M.L.C.S. (2009). Cytotoxicity and regenerative proliferation as the mode of action for diuron-induced urothelial carcinogenesis in the rat. Toxicol Sci [Epub ahead of print], doi:10.1093/toxsci/kfp241.

Sancheti, G., Goyal, P.K. (2006) Effect of rosmarinus officinalis in modulating 7,12dimethylbenz(a)anthracene induced skin tumorigenesis in mice. Phytother Res 20(11), 981-6.

Seiler, J.P. (1978) Herbicidal phenylalkylureas as possible mutagens I. Mutagenicity tests with some urea herbicides. Mutat Res 58(2-3), 353-9.

Slaga, T.J. (1986). SENCAR mouse skin tumorigenesis model versus other strains and stocks of mice. Environ Health Perspect 68, 27-32.

Tsuda, H., Park, C.B., Moore, M.A. (1999). Short- and medium-term carcinogenicity tests: Simple initiation-promotion assay systems. In The use of short- and medium-term tests for carcinogens and data on genetic effects in carcinogenic hazard evaluation (D.B. McGregor, J.M. Rice, S Venitt, eds). Vol. 146, pp 20349. IARC Scientific Publications, Lyon, France.

USEPA (2004). Chemicals evaluated for carcinogenic potential. Office of Pesticide Programs, Health Effects Division. Science Information Management Branch, 106.

Watt, F.M. (1998). Epidermal stem cells: markers, patterning and the control of stem cell fate. Phil Trans $R$ Soc Lond B 353, 831-7.

Wattenberg, E.V. (2007) Palytoxin: exploiting a novel skin tumor promoter to explore signal transduction and carcinogenesis. Am J Physiol Cell Physiol 292, 24-32. 
Williams, G.M. (1999) Chemically induced preneoplastic lesions in rodents as indicators of carcinogenic activity. In The use of short- and medium-term tests for carcinogens and data on genetic effects in carcinogenic hazard evaluation (D.B. McGregor, J.M. Rice, S. Venitt, eds), Vol. 146, pp. 185-202. IARC Scientific Publications, Lyon, France.

Witte, I., Plappert, U., de Wall, H., Hartmann, A. (2007). Genetic toxicity assessment: employing the best science for human safety evaluation - Part III: The Comet Assay as an alternative to in vitro clastogenicity tests for early drug candidate selection. Toxicol Sci 97(1), 21-26.

Yuspa, S.H., Hennings, H., Saffiotti, U. (1976). Cutaneous chemical carcinogenesis: past, present and future. J Invest Dermatol 67(1), 199-208.

Yuspa, S.H., Hennings, H., Lichti, U. (1981). Initiator and promoter induced specific changes in epidermal function and biological potential. J Supramol Struct Cell Biochem 17(3), 245-57. 


\section{MANUSCRITO}

O manuscrito apresentado a seguir, já submetido para publicação em Toxicologic Pathology (ISSN 0192-6233, Fator de Impacto $2008=1.642$ ), compreende os trabalhos de Iniciação Científica e de Mestrado da biomédica Bianca Ferrucio, realizados no Departamento de Patologia, Faculdade de Medicina de Botucatu, UNESP, no período 2006-2010.

\section{Auxílios financeiros}

FAPESP Processos \# 06/60506-1, 06/04630-5 e 08/01809-0;

TOXICAM - Núcleo de Avaliação do Impacto Ambiental sobre a Saúde Humana, Faculdade de Medicina de Botucatu, UNESP. 


\section{Evaluation of diuron [3-(3,4-dichlorophenyl)-1,1-dimethyl urea] in a two-stage mouse skin carcinogenesis assay}

Bianca Ferrucio* - biferrucio@ hotmail.com

Carla Adriene da Silva Franchi* - carlafranchi@ fmb.unesp.br

Natália Ferreira Boldrin* - nataliaboldrin@gmail.com

Maria Luiza Cotrim Sartor de Oliveira* - mdeolive@ fmb.unesp.br

João Lauro Viana de Camargo* - decam@fmb.unesp.br

*Center for the Evaluation of the Environmental Impact on Human Health (TOXICAM), Department of Pathology, Botucatu Medical School, UNESP - São Paulo State University, Botucatu, São Paulo, Brazil. 18618-000

Address correspondence to:

João Lauro Viana de Camargo, M.D. Ph.D.

Departamento de Patologia, Faculdade de Medicina, UNESP

18618-000, Botucatu, São Paulo, Brasil

E-mail: decam@fmb.unesp.br

Phone number: +55 14 38116238; Fax: +55 1438152348

The present work constitutes original research article. It has not been published and it is not under consideration for publication elsewhere. 


\begin{abstract}
Diuron [3-(3,4-dichlorophenyl)-1,1-dimethyl urea] is a herbicide with carcinogenic activity in rats and mice which have developed respectively urothelial and mammary gland tumors in long-term studies. Accordingly, diuron has been categorized as a "likely human carcinogen" by the USEPA. Although the carcinogenesis initiating activity of diuron has been reported in an early initiation-promotion mouse skin study, its genotoxic potential has been disputed. It is necessary to clarify the mode of action through which it has caused rodent neoplasia and verify its relevance to humans. Herein, two experiments were developed to verify the initiating and promoting potentials of diuron in a 23 - and a 21 -week long mouse skin carcinogenesis protocol. In one, dimethylsulphoxide (DMSO) was the solvent for the herbicide; in the other, acetone was the alternative solvent in order to verify if DMSO had inhibitory influence on a potential cutaneous carcinogenic activity. The adopted schedule for the tumor promoting agent 12-O-tetradecanoylphorbol 13-acetate (TPA) resulted in skin ulcers, evidencing the need for careful selection of TPA dose levels and frequency of application in this model. In both studies diuron did not exert any influence on the skin carcinogenesis process, in contrast with results already reported in the literature.
\end{abstract}




\section{INTRODUCTION}

Diuron [3-(3,4-dichlorophenyl)-1,1-dimethyl-urea] is a widely used herbicide for weed control in soy, cotton, sugarcane, citrus fruits, wheat and coffee crops, as well as in non-crop areas such as airport runways, railroads and oil-pipes. Occupational exposure is the main concern about this herbicide. Agricultural workers frequently neglect safety practices, including the use of personal protective equipments that aim to avoid dermal exposure during pesticides mixing or application (Carpenter et al., 2002; Perry et al., 2002). Moreover, skin protective equipment (SPE) may fail to cover the skin surface entirely and transfer may occur when touching the contaminated exterior of the SPE; additionally, SPE may enable permeation depending on the manipulated substance and/or the SPE material (Brouwer et al., 2005).

Diuron was recognized as carcinogenic to rodents orally exposed to $2,500 \mathrm{ppm}$ through the feed in two-year long bioassays (Iyer, 2002). In those studies, Wistar rats developed urothelial papillomas and carcinomas, and NMRI female mice developed mammary gland adenocarcinomas. According to these evidences, the U.S. Environmental Protection Agency has categorized this herbicide as "likely human carcinogen" (US Environmental Protection Agency, 2004). Since diuron is released for agricultural use, it is necessary to clarify the mode of action (MOA) through which this product has caused rodent neoplasia and verify whether it is relevant to humans. In a recent study from this laboratory it was demonstrated that diuron and/or its metabolites induce urinary bladder carcinogenesis in Wistar rats through direct chemical cytotoxicity followed by regenerative cell proliferation; the specific mechanism of action, however, has not been clarified yet (Rocha et al., 2009).

Despite having been evaluated in several in vitro and mammalian in vivo genetic toxicology assays, the genotoxic potential of diuron is disputable, depending on the 
experimental protocol, dose levels and endpoints evaluated (Grutman et al., 1984; Iyer, 2002; Liu, 2001). A weak mutagenic activity of diuron was reported in a metabolically activated Ames' test with Salmonella thyphimurium, but results were negative in a mouse bone marrow micronucleus assay (Seiler, 1978). When tested in Swiss mice, diuron was positive in the bone marrow micronucleus assay (Agrawal et al., 1996) and in the germ cells dominant lethal assay (Agrawal \& Mehrotra, 1997). However, in the Mutatox test with a dark variant (M169) of the Photobacterium phosphoreum the genotoxicity of diuron resulted only suspected (Canna-Michaelidou \& Nicolaou, 1996).

The biological significance of positive results obtained in genotoxicity cytogenetic assays has been questioned based on their low predictivity of rodent carcinogenicity (Witte et al., 2007). Additionally, it was suggested that the comet assay (single-cell gel assay) is the most preferable method to assess genotoxicity once it is relatively insensitive to cytotoxicity; hence, false positive results are less frequent, even when high concentrations of the test compounds clearly affect cell viability (Witte et al., 2007). Previous studies from this laboratory reported absence of diuron genotoxicity in the standard alkaline version of the comet assay with urothelial and peripheral blood cells (Nascimento et al., 2006). Besides, a modified version of the comet assay developed in vitro with $\mathrm{CHO}$ cells indicated that diuron also does not induce DNA cross-links (Rocha et al., 2009).

In an early skin initiation-promotion carcinogenesis study with Swiss female mice, the initiating activity of diuron (supplied by Bharat Pulverizing Mills, Bombay) was registered when applied in consecutive doses $(250 \mathrm{mg} / \mathrm{kg} \mathrm{b.w.,} \mathrm{three} \mathrm{times/week} \mathrm{for}$ three weeks) followed by applications of the tumor promoter 12-O-tetradecanoyl phorbol 13-acetate (TPA) during 52 weeks (Antony et al., 1989). This observation may suggest that diuron is a genotoxin, once every initiating agent should be assumed to be 
genotoxic (Pitot III \& Dragan, 2001). However, no initiating potential was verified by Antony et al. (1989) when diuron was applied at a single $250 \mathrm{mg} / \mathrm{kg}$ b.w. dose, which could indicate a possible threshold, inconsistent with its supposed initiating potential. In this case, a promoting influence on the mouse skin carcinogenesis process would be more likely, since in this condition a threshold level and a non-genotoxic MOA would be more suitable (Williams, 1999). Antony et al. (1989) did not justify the diuron dose levels they evaluated, adding to the unsubstantial aspect of their study.

Herein, the initiating potential of diuron was evaluated in a mouse skin carcinogenesis protocol aimed to reproduce the Antony et al. (1989) experimental design. Besides, the promoting potential was also evaluated using basically the same model. Two experiments were developed; in the first one, dimethylsulphoxide (DMSO) was the solvent for diuron, as used by Antony et al. (1989). DMSO has been reported to reduce tumor responses in the two stage skin carcinogenesis assay. In DMBA-initiated Sencar mice, the promoting activity of TPA diluted in DMSO was decreased by up to 99\% when compared to TPA diluted in acetone (Slaga \& Fischer, 1983). In Tg.AC mice, the use of DMSO as the TPA solvent reduced the skin tumor response by up to $66 \%$, while administration of TPA in acetone caused nearly maximal tumor responses (Stoll et al, 2001). The reason for this decreased promoting response, however, was not explained in both studies. Hypothetically, DMSO rapidly penetrates through the skin barrier, carrying noxious molecules like carcinogens, in such a way that the contact with epithelial cells is too short to cause damage (Volden et al., 1983). Considering the possibility that DMSO might have masked the diuron carcinogenic potential in the first experiment, which resulted negative for carcinogenesis, acetone was used as an alternative solvent in the second study. 
The present studies aimed to evaluate the carcinogenic potential of diuron in a female Swiss mouse skin carcinogenesis assay. Besides, the potential role of DMSO or acetone - the herbicide solvents - was also investigated in this process. Regardless of the solvent used, diuron did not exert any carcinogenesis initiating or promoting activities in the mouse skin.

\section{MATERIAL AND METHODS}

\section{Animals and chemicals}

These experiments were approved by the Committee for Ethics in Animal Experimentation of the UNESP Medical School, SP, Brazil [protocols 2006-567 and 2008-672]. Four-week-old Swiss female mice obtained from the Multidisciplinary Center for Biological Investigation (CEMIB, UNICAMP, Campinas, SP, Brazil) were kept in polypropylene cages (five animals/cage) with metallic grill covers, and maintained in a room at $22 \pm 2{ }^{\circ} \mathrm{C}, 55 \pm 10 \%$ humidity and a $12 \mathrm{~h}$ light/dark cycle. Animals were provided with commercial pelletized diet (Nuvital, Nuvilab, Curitiba, PR, Brazil) and tap water ad libitum.

After a two-week acclimatization period, mice were randomized to the experimental groups according to body weights. The dorsal skin was shaved using electric clippers one day before the first treatment and weekly thereafter, except for the untreated control.

All animals were daily examined for clinical signs. Incidence, number and size of gross papillary tumors and ulcers were registered. Body weights, food and water consumptions were measured weekly. Mice were euthanized by carbon dioxide inhalation at the end of the experiments or when bearing severe cutaneous ulcers. At necropsy, patchy skin samples were collected, including both normal and ulcerated 
areas. Skin patches with lesions (ulcers and tumors) were cut randomly for histological analyses. Liver, spleen, kidneys and lymph nodes were also collected and weighted. All tissues were fixed in $10 \%$ buffered formalin, followed by routine histological processing.

\section{Treatments}

Positive control groups were initiated with 9,10-dimethyl-1,2-benzantracene (DMBA, Sigma-Aldrich Co., St Louis, MO), and promoted with 12-Otetradecanoylphorbol 13-acetate (TPA, Sigma-Aldrich Co, St Louis, MO). Diuron (CAS No. 30-54-1) was purchased from Sigma Chemical Co., St. Louis, MO.

The chemical substances were alternatively or successively applied with micropipette on a shaved dorsal area of approximately $9 \mathrm{~cm}^{2}$, at the following concentrations: DMBA, $52 \mu \mathrm{g} / 100 \mu \mathrm{L}$ acetone; TPA, $3.5 \mu \mathrm{g} / 100 \mu \mathrm{L}$ acetone; diuron, $250 \mathrm{mg} / \mathrm{kg}$ b.w. dissolved in $100 \mu \mathrm{L}$ DMSO or in $300 \mu \mathrm{L}$ acetone; acetone, $100 \mu \mathrm{L}$ and $300 \mu \mathrm{L}$ (vehicle controls). DMBA was applied once and TPA was applied three times/week until the end of each experiment. Diuron was applied three times/week during three weeks when tested as an initiator, and three times/week until the end of each experiment when tested as a promoter. Acetone was applied once when tested as an initiator and three times/week until the end of the experiment when tested as a promoter.

Experiment-1 consisted of six groups with 20 animals each (Figure 1): Group 1 (G1), untreated control; Group 2 (G2), DMBA followed by TPA; Group 3 (G3), acetone $100 \mu \mathrm{L}$ followed by TPA; Group 4 (G4), diuron/DMSO followed by acetone $100 \mu \mathrm{L}$; Group 5 (G5), diuron/DMSO followed by TPA; Group 6 (G6), DMBA followed by 
diuron/DMSO. A three-day interval was given between initiation and promotion treatments in groups G4 and G5, and one-week interval in groups G2, G3 and G6.

Experiment-2 consisted of nine groups with 15 animals each (Figure 2): Group 1

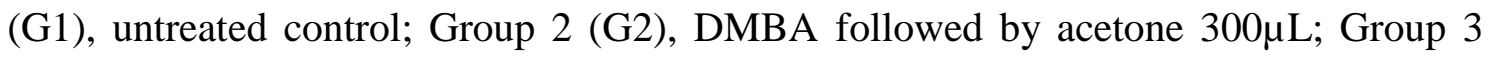
(G3), DMBA followed by diuron/acetone; Group 4 (G4), DMBA followed by diuron/DMSO; Group 5 (G5), acetone $100 \mu \mathrm{L}$ followed by diuron/acetone; Group 6 (G6), acetone $100 \mu \mathrm{L}$ followed by diuron/DMSO; Group 7 (G7), DMBA followed by TPA; Group 8 (G8), diuron/acetone followed by TPA; Group 9 (G9), diuron/DMSO followed by TPA. One-week interval was given between initiation and promotion treatment in all groups.

Experiments -1 and -2 were planned to last until week 25 . However, a humane decision was taken to anticipate termination at weeks 23 and 21 respectively, owing to the high number of animals with severe skin ulcers.

\section{Statistical analysis}

The Fisher's Exact Test was applied for comparison of skin lesions incidence between experimental groups and for comparison between ulcer-bearing and "nonulcer"-bearing animals in relation to the incidences of carcinomas per group. The MannWhitney test for independent samples was used to compare the variation of the number of papillary tumors per mouse between ulcer-bearing and "non-ulcer"-bearing animals of the positive control group in Experiment-2. Results were considered significant when $\mathrm{p}<0.05$. 


\section{RESULTS}

From the first to the last week of experiment, mean body weights raised from $25.32 \pm 0.20 \mathrm{~g}$ to $39.32 \pm 1.82 \mathrm{~g}$ in the first study, and from $26.63 \pm 0.25 \mathrm{~g}$ to $38.85 \pm$ $1.60 \mathrm{~g}$ in the second study (data not shown). Taking into account the lowest and highest mean body weights, diuron doses ranged from $6.30 \mathrm{mg} /$ application to 9.80 mg/application, representing $250 \mathrm{mg} / \mathrm{kg}$ b.w. Food and water consumptions varied between groups in both studies (data not shown), but apparently did not affect significantly mice body weight gain and viability since all animals grew progressively during the studies.

Table I shows the incidences of macroscopic and histological lesions verified in the Experiment-1 (Figure 3). Only the positive control group (G2, DMBA+TPA) yielded a significantly increased incidence (100\%) of gross papillary tumors, which started to appear at week 7; the other two groups also treated with TPA presented few animals with tumors, irrespective of previous exposure to acetone (G3) or diuron/DMSO (G5). Animals treated with diuron either at the initiation (G4, G5) or promotion steps (G6) did not develop significant incidences of papillary tumors, when compared with the controls. From week 14 and as the experiment was extended, animals treated with TPA (G2, G3 and G5) developed skin ulcers in significantly higher incidences when compared with the other groups. Histologically, epidermal hyperplasia was verified in all treated groups, but only the groups exposed to TPA (G2, G3, G5) showed significantly higher incidences of accentuated hyperplasia, characterized by more than four cell layers (acanthosis) and hypergranulosis. Most of the skin papillary tumors were papillomas, some of them with dysplastic epithelial foci; few of them were keratoacanthomas. Well-differentiated squamous cell carcinomas were found within 
ulcerated lesions, their incidences being significantly higher in the groups treated with TPA.

Table II shows the incidences of cutaneous lesions in the Experiment-2 (Figure 3). Again, macroscopic papillary tumors were only registered in the TPA-treated groups (G7, G8 and G9) but only the positive control group (G7, DMBA+TPA) yielded a significantly increased incidence $(100 \%)$ of tumors, which started to appear at week 7 . Starting from week 13, ulcers occurred in animals exposed to TPA during the promotion step, irrespective of previous initiating treatment with DMBA (G7) or with diuron diluted in acetone (G8) or in DMSO (G9). Histologically, lesions were similar to those found in the Experiment-1. Accentuated acanthosis occurred in all animals treated with TPA. Squamous cell carcinomas occurred at the same incidences in the positive control group (G7) and in the groups initiated with diuron diluted either in acetone or DMSO and promoted with TPA (G8 and G9).

In Experiment-2, gross papillary tumor counts per mouse were recorded at weeks 9, 12 and 16. Since in diuron-initiated TPA-promoted animals (G8 and G9) these tumors occurred in few animals, which developed no more than one papillary tumor each, tumor countings were restricted to the positive control group (G7, Table III). In general, at week 16 ulcer-bearing animals presented less tumors when compared with "non-ulcer"-bearing animals. The association between the number of gross papillary tumors and ulcers development was statistically evaluated considering tumor multiplicity in ulcer-bearing and in "non-ulcer"-bearing animals (Table IV). The number of papillary tumors in ulcer-bearing animals decreased by $34.6 \%$ between weeks 9 and 16 and by $43.7 \%$ between weeks 12 and 16; in "non-ulcer"-bearing animals, the number of tumors increased by $102.6 \%$ between weeks 9 and 16, and by $14.2 \%$ between weeks 12 and 16 . These observations indicate that skin ulcer 
development compromised the persistence of papillary tumors while in "non-ulcer"bearing mice, the multiplicity of these tumors increased continuously throughout the weeks.

Tables V and VI present the comparison between ulcer-bearing and "non-ulcer"bearing animals in relation to the incidences of histologically-detected carcinomas in both experiments. In Experiment-1, carcinomas occurred at incidences of 56\%, 50\% and $75 \%$, only in the animals that developed ulcers during TPA treatment (G2, G3 and G5 respectively). Association between ulcers and carcinomas was statistically significant in those groups, pointing to the critical role of TPA in establishing ulcerations and carcinomas. In the Experiment-2, carcinomas occurred in ulcer-bearing animals at incidences of $42 \%, 60 \%$ and $60 \%$ in the groups G7, G8 and G9, all of them treated with TPA during the promotion step. One "non-ulcer" animal in the positive control group (G7, DMBA+TPA) developed a papillary carcinoma. The association between ulcers and carcinomas was significant for group G8 $(p=0,044)$, but not for G7 and G9.

\section{DISCUSSION}

In the present studies, gross skin papillary tumors were registered in significantly higher incidences, as expected, in the positive control group, treated sequentially with DMBA and TPA. In remarkably lower incidences, papillary tumors were also registered in other groups treated with TPA in the promotion step, irrespective of the initiating treatment with diuron/DMSO, diuron/acetone or only acetone. When diuron was provided during the promotion step, despite being diluted in DMSO or acetone, it did not induce any papillary tumor or other relevant skin lesions, irrespective of previous treatment with DMBA or acetone. If diuron had a genotoxic/initiating potential, it would have induced skin tumors after being successively applied during the 
extended period that characterizes the promotion step, once initiating agents are often complete carcinogens (Iversen, 1994).

Therefore, under the experimental conditions adopted, diuron did not exert carcinogenesis initiating or promoting activities in the Swiss female mouse skin, and varying the herbicide solvent did not influence the results. The present data strongly diverge from previous findings that indicated tumor initiatory activity of diuron in a mouse skin assay (Antony et al., 1989). Besides, they suggest that diuron is not a genotoxic agent, what is in line with information from this laboratory that reported nongenotoxicity of the herbicide under two different comet assay protocols (Nascimento et al., 2006; Rocha et al., 2009).

A striking observation in these studies was the development of severe skin ulcers and histologically-detected carcinomas in the groups exposed to TPA. This nongenotoxic compound has been reported to be a weak but complete carcinogen when applied repeatedly in the hairless Oslo mouse skin, in which even a positive doseresponse has been demonstrated (Iversen, 1985; 1994). In the Iversen's studies, $6.17 \mu \mathrm{g} / 100 \mu \mathrm{L}$ of TPA diluted in acetone applied twice a week to non-initiated mouse skin produced $9 \%$ incidence of tumor-bearing animals after 55 weeks. The NTP has designed a protocol in which $5 \mu \mathrm{g}$ of TPA applied once a week for 51 weeks was sufficient to induce tumors in $13 \%$ of non-initiated Swiss female mouse (National Toxicology Program, 1996). In a recent review on the multistage skin chemical carcinogenesis protocol, it was suggested that TPA should be applied only once or twice a week, depending on the dose and mouse strain used (Abel et al., 2009).

In the early Antony et al. (1989) study, which reported initiating potential of diuron when applied in multiple doses, TPA $5 \mu \mathrm{g}$ was applied three times a week, for 52 weeks. Thus, it is possible that the high frequency of TPA applications and the dose 
levels adopted by Antony et al. (1989) were sufficient to induce tumors even in the absence of any initiating procedure, leading to the $73 \%$ tumor incidence they verified in that group. This possibility, however, does not explain the absence of tumors verified by those authors in the group initiated with a single dose of diuron and promoted with the same TPA schedule (Antony et al., 1989), and this controversy remains to be elucidated. The TPA dose level used in our studies was slightly lower $(3.5 \mu \mathrm{g} / 100 \mu \mathrm{L})$ than those suggested by others (NTP, 1996; Abel et al., 2009) but was applied three times a week, the same as done by Antony et al. (1989) and in dissonance with Abel et al. (2009) recommendations. It is intriguing that Antony et al. (1989) did not account on histological lesions and did not refer to ulcer or carcinoma developments in their study. The occurrence of these lesions in the current study is discussed below.

The present experiments were planned to last 25 weeks, as indicated previously. This duration was based on the verification of conspicuous development of papillary tumors at this moment in the Antony et al. (1989) study, and also on other reports using the mouse skin carcinogenesis protocol, which did have the same or shorter lengths (Chan et al., 2004; Ridd et al., 2006; Chaudhary et al., 2009). However, due to the severe ulcers developed in the TPA-treated animals, experiments were terminated at weeks 23 and 21 for humane reasons. Highly reproducible papilloma burden is expected after 20 weeks of promotion, and progression to squamous cell carcinoma usually occurs within 20 to 50 weeks of treatment with tumor-promoting agent (Abel et al., 2009). Therefore, it can be assumed that the experiments' duration adopted was sufficient to detect potentially diuron-induced skin papillary tumors.

High incidence of skin ulcers in groups treated successively with TPA is a relatively common finding due to the irritating properties of this chemical, especially in the Swiss mouse skin (Klein-Szanto et al., 1986; National Toxicology Program, 1996). 
Herein, it was demonstrated that several papillary tumors were eradicated by the process of ulceration, as the number of tumors per mouse decreased concurrently with ulcers development.

Similarly to the ulcer incidences, the significantly higher incidences of histologically-detected carcinomas in the TPA-treated groups is probably a consequence of TPA cytotoxicity, regardless of the initiating treatment. Besides TPA being a weak skin carcinogen (Iversen, 1985; 1994), it is possible that the repetitive cell injury it provoked led to epithelial disruption and ulceration, inducing the surviving epithelium at the ulcer borders to regenerate and eventually progress to malignancy. This possibility is supported by the strong association registered between carcinomas and ulcers. Although a significant positive association was not verified in all groups from Experiment-2, there was a clear biological relationship between ulcers and carcinomas, and it is very likely that the absence of statistical significance of this association may be accounted on the size of these groups. Additionally, there are no significant differences between the incidences of carcinomas in the positive control group and the other TPAtreated animals in both Experiment-1 and -2, suggesting that TPA treatment itself, and not the initiating treatment, was critical for the development of epithelial malignancies. These observations reinforce the recommendations that experimental skin treatment by TPA should follow careful selection of doses and frequency of applications (Abel et al., 2009) in order to avoid incidental events that may hinder the interpretation of results due to the citotoxicity of this compound.

At relatively high dietary concentration $(2,500 \mathrm{ppm})$ diuron is carcinogenic to the rat urinary bladder mucosa. The mode of action the herbicide plays on that target tissue is probably through citotoxicity followed by sustained urothelial regeneration (Rocha et al., 2009). In the mouse skin, diuron was associated with significantly higher 
incidences of epidermal hyperplasia - an indirect indication of enhanced cell proliferation - only when associated to DMBA or TPA; otherwise, when applied with either DMSO or acetone, the incidences of epithelial hyperplasia were not relevant. Therefore, contrary to what is observed in the rat urinary mucosa, diuron seems not to induce epidermal cell proliferation. Overall, the present data indicate that diuron acts neither as an initiator nor as a promoter of carcinogenesis in the female Swiss mouse skin assay. Taking into account the limits of extrapolation between rodent and human skin biological events (Enzmann et al., 1998), it could be assumed that potential cutaneous occupational exposure to this herbicide probably does not represent a risk for human skin cancer development.

\section{ACKNOWLEDGMENTS}

This work was supported by the Fundação de Amparo à Pesquisa do Estado de São Paulo (FAPESP) [Grants \# 06/60506-1, 06/04630-5 and 08/01809-0] and Núcleo de Avaliação do Impacto Ambiental sobre a Saúde Humana (TOXICAM). Paulo Roberto Cardoso, Maria Luiza Falaguera, Paulo Cesar Georgete and Cristina Aparecida Alquati Dorico provided helpful technical assistance.

\section{REFERENCES}

Abel, E.L., Angel, J.M., Kiguchi, K., and DiGiovanni, J. (2009). Multi-stage chemical carcinogenesis in mouse skin: Fundamentals and applications. Nat protoc 4(9), $1350-62$.

Agrawal, R.C., Kumar, S., and Mehrotra, N.K. (1996). Micronucleus induction by diuron in mouse bone marrow. Toxicol Lett 89, 1-4. 
Agrawal, R.C., and Mehrotra, N.K. (1997). Effect of diuron on germ cells of mice. Indian J Exp Biol 35(11), 1256-7.

Antony, M., Shukla, Y., and Mehrotra, N.K. (1989). Tumour initiatory activity of a herbicide diuron on mouse skin. Cancer Lett 48, 125-8.

Brouwer, D.H., Aitken, R.J., Oppl, R., and Cherrie, J.W. (2005). Concepts of skin protection: considerations for the evaluation and terminology of the performance of skin protective equipment. J Occup Environ Hyg 2(9), 425-34.

Canna-Michaelidou, S., and Nicolaou, A.S. (1996). Evaluation of the genotoxicity potential (by Mutatox ${ }^{\mathrm{TM}}$ test) of ten pesticides found as water pollutants in Cyprus. Sci Total Environ 193, 27-35.

Carpenter, W.S., Lee, B.C., Gunderson, P.D., and Stueland, D.T. (2002). Assessment of personal protective equipment use among midwestern farmers. Am J Ind Med 42, 236-47.

Chan, K.S., Sano, S., Kiguchi, K., Anders, J., Komazawa, N., Takeda, J., and DiGiovanni, J. (2004). Disruption of Stat3 reveals a critical role in both the initiation and the promotion stages of epithelial carcinogenesis. $J$ Clin Invest 114(5), 720-8.

Chaudhary, S.C., Alam, M.S., Siddiqui, M.S., and Athar, M. (2009). Chemopreventive effect of farnesol on DMBA/TPA-induced skin tumorigenesis: Involvement of inflammation, Ras-ERK pathway and apoptosis. Life Sci 85(5-6), 196-205.

Enzmann, H., Bomhard, E., Iatropoulos, M., Ahr, H.J., Schlueter, G., and Williams, G.M. (1998) Short- and intermediate-term carcinogenicity testing - a review. Part 1: the prototypes mouse skin tumour assay and rat liver focus assay. Food Chem Toxicol 36, 979-95. 
Fu, W., McCormick, T., Qi, X., Luo, L., Zhou, L., Li, X., Wang, B.C., Gibbons, H.E., Abdul-Karim, F.W., and Gorodeski, G.I. (2009). Activation of P2X7-mediated apoptosis inhibits DMBA/TPA-induced formation of skin papillomas and cancer in mice. BMC Cancer 9, 114.

Grutman, G., Schoofs, L., Lontie, J.F., and van Larebeke, N. (1984). The mutagenicity in prokaryotes of herbicides. Residue Rev 91, 1-46.

Iversen, O.H. (1985). TPA (12-O-tetradecanoyl-phorbol-13-acetate) as a carcinogen for mouse skin. A positive dose-response relationship. Virchows Arch B Cell Pathol Incl Mol Pathol 49(2), 129-35.

Iversen, O.H. (1994). A course of very small doses of DMBA, each of them allegedly with no promoting potency, acts with clear synergistic effect as a strong promoter of DMBA-initiated mouse skin carcinogenesis. A comparison of the tumorigenic and carcinogenic effects of DMBA (7,12-dimethylbenz-alphaanthracene) and TPA (12-O-tetradecanoyl-phorbol-13-acetate) used as initiators and promoters in classical two-stage experimental protocols. APMIS Suppl 41, $1-38$.

Iyer, P. (2002). Evidence on the development and reproductive toxicity of diuron. Draft. Reproductive and Cancer Hazard Assessment Section. Office of Environmental Health Hazard Assessment, California Environmental Protection Agency, 43.

Klein-Szanto, A.J.P., Conti, C.J., Aldaz, C.M., Clapp, N., Nesnow, S., and Slaga, T.J. (1986). Effects of chronic topical application of 1 2-O-tetradecanoylphorbol-1 3acetate on the skin and internal organs of SENCAR mice. Environ Health Perspect 68, 75-80.

Liu, J. (2001). Phenylurea herbicides. In Handbook of Pesticide Toxicology - Agents (K.E. Krieger, ed.), Vol. 2, pp. 1521-3. Academic Press, San Diego. 
Nascimento, M.G., de Oliveira, M.L.C.S., Lima, A.S., and de Camargo, J.L.V. (2006). Effects of diuron [3-(3,4-dichlorophenyl)-1,1-dimethylurea] on the urinary bladder mucosa of male Wistar rats. Toxicology 224, 66-73.

National Toxicology Program (1996). Comparative initiation/promotion skin paint studies of $\mathrm{B} 6 \mathrm{C} 3 \mathrm{~F}_{1}$ mice, Swiss $\left(\mathrm{CD}-1^{\circledR}\right)$ mice, and SENCAR mice. NTP TR 441, NIH Publication No. 96-3357. NIH, Research Triangle Park, NC.

Perry, M.J., Marbella, A., and Layde, P.M. (2002). Compliance with required pesticidespecific protective equipment use. Am J Ind Med 41, 70-3.

Pitot III, H.C., and Dragan, Y.P. (2001). Chemical carcinogenesis. In Casarett \& Doull's Toxicology the Basic Science of Poisons (C.D. Klaassen, ed), pp. 241 319. McGraw-Hill, New York.

Ridd, K., Zhang, S.D., Edwards, R.E., Davies, R., Greaves, P., Wolfreys, A., Smith, A.G., and Gant, T.W. (2006). Association of gene expression with sequential proliferation, differentiation and tumor formation in murine skin. Carcinogenesis 27(8), 1556-66.

Rocha, M.S., Nascimento, M.G., Cardoso, A.P.F., Lima, P.L.A., Zelandi, E.A., de Camargo, J.L.V., and de Oliveira, M.L.C.S. (2009). Cytotoxicity and regenerative proliferation as the mode of action for diuron-induced urothelial carcinogenesis in the rat. Toxicol Sci [Epub ahead of print], doi:10.1093/toxsci/kfp241.

Seiler, J.P. (1978) Herbicidal phenylalkylureas as possible mutagens I. Mutagenicity tests with some urea herbicides. Mutat Res 58(2-3), 353-9. 
Slaga, T.J., and Fischer, S.M. (1983). Strain differences and solvent effects in mouse skin carcinogenesis experiments using carcinogens, tumor initiators and promoters. Prog Exp Tumor Res 26, 85-109.

Stoll, R.E., Furst, S.M., Stoltz, J.H., Lilly, P.D., and Mennear, J.H. (2001). Dermal carcinogenicity in transgenic mice: effect of vehicle on responsiveness of hemizygous Tg.AC mice to phorbol 12-myristate 13-acetate (TPA). Toxicol Pathol 29(5), 535-40.

US Environmental Protection Agency (2004). Chemicals evaluated for carcinogenic potential. Office of Pesticide Programs, Health Effects Division. Science Information Management Branch, 106.

Volden, G., Thorud, E., and Iversen, O.H. (1983). Inhibition of methylcholanthreneinduced skin carcinogenesis in hairless mice by the membrane-labilizing agent DMSO. Br J Dermatol 109(25), 133-6.

Williams, G.M. (1999) Chemically induced preneoplastic lesions in rodents as indicators of carcinogenic activity. In The use of short- and medium-term tests for carcinogens and data on genetic effects in carcinogenic hazard evaluation (D.B. McGregor, J.M. Rice, S. Venitt, eds), Vol. 146, pp. 185-202. IARC Scientific Publications, Lyon, France.

Witte, I., Plappert, U., de Wall, H., and Hartmann, A. (2007). Genetic toxicity assessment: employing the best science for human safety evaluation - Part III: The Comet Assay as an alternative to in vitro clastogenicity tests for early drug candidate selection. Toxicol Sci 97(1), 21-26. 


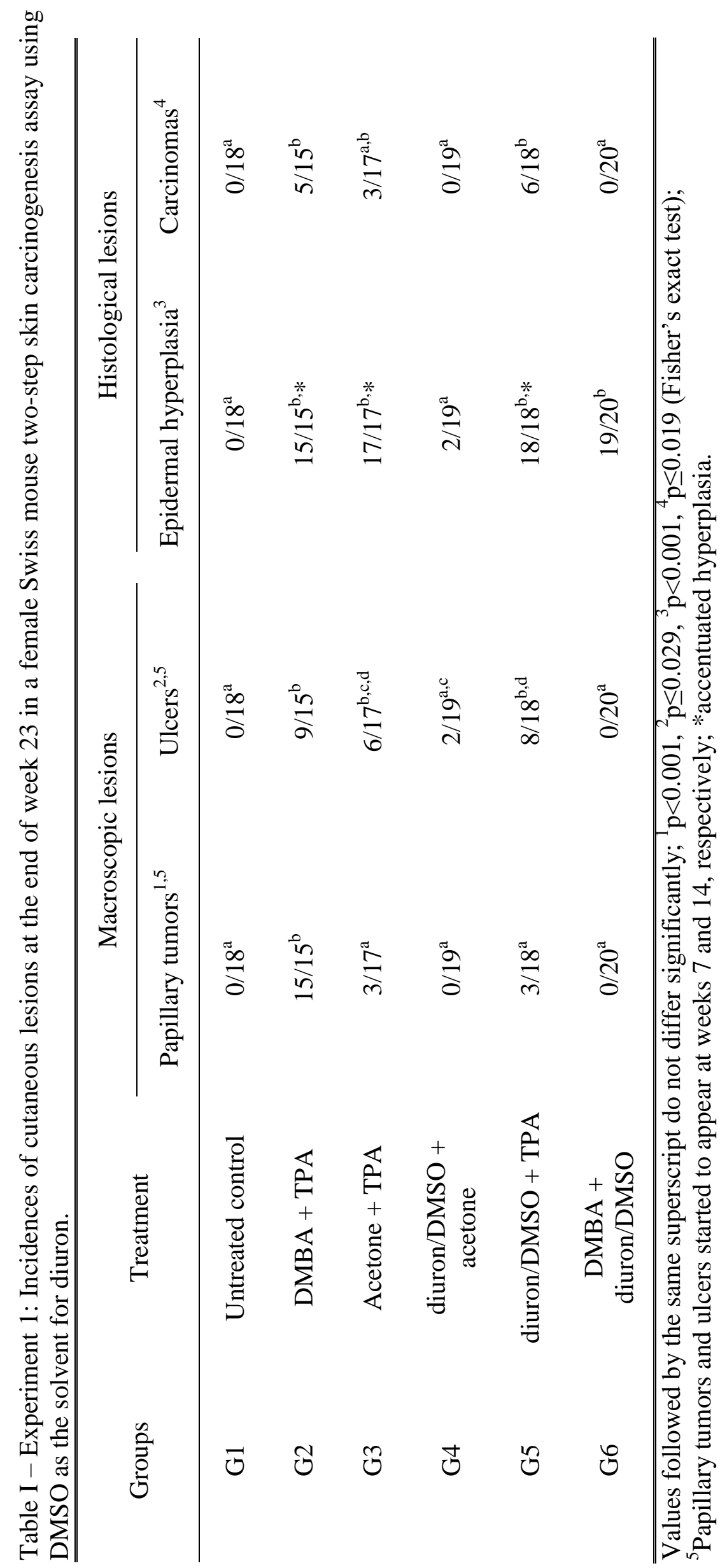




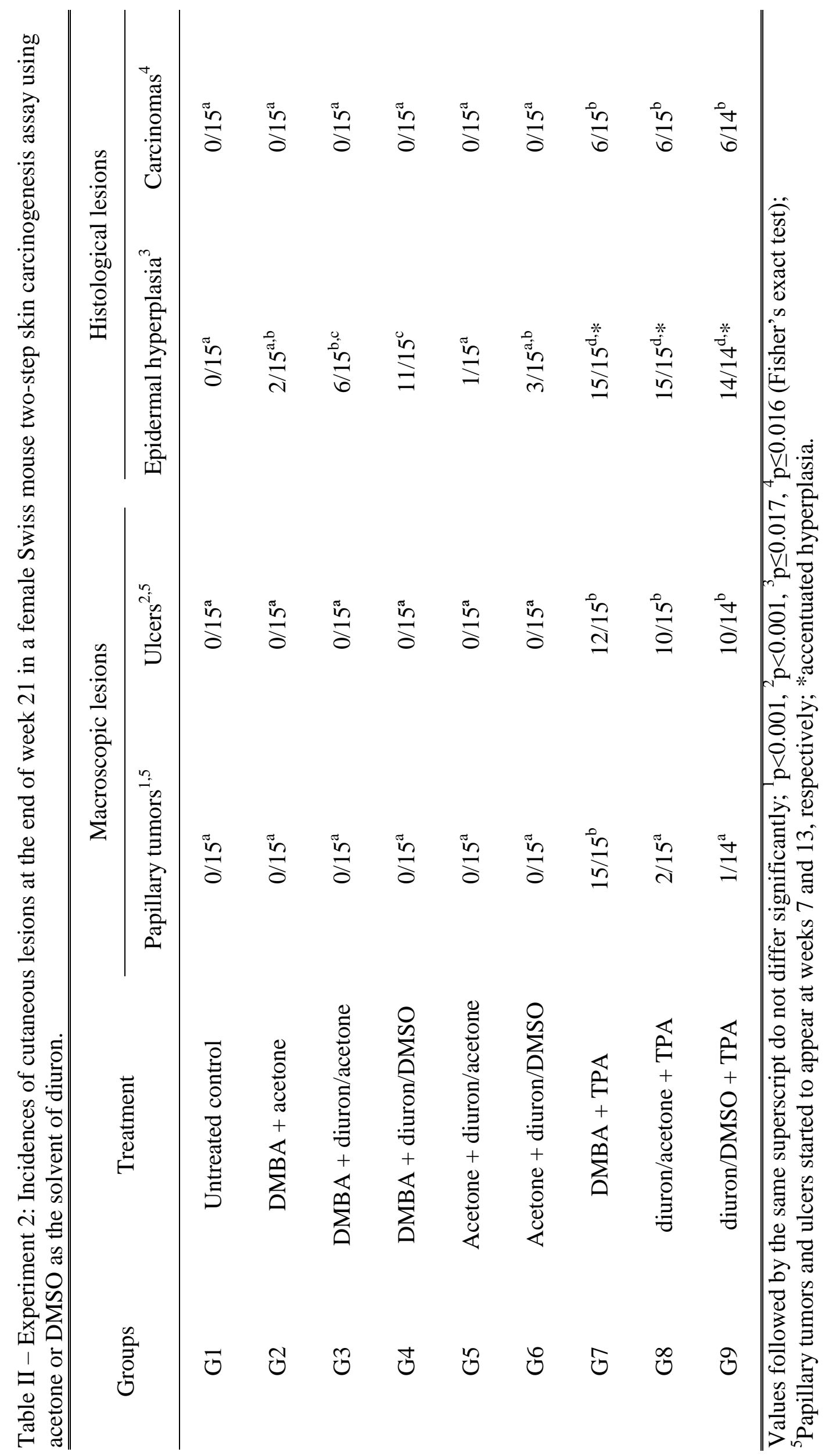


Table III: Female Swiss mouse two-step skin carcinogenesis bioassay. Experiment 2 - Number of papillary tumors per mouse and ulcers occurrence at week 16 in the positive control group (G7, DMBA+TPA).

\begin{tabular}{ccccc}
\hline \multirow{3}{*}{$\begin{array}{c}\text { Animal } \\
\text { identification }\end{array}$} & \multicolumn{3}{c}{ Week } & $\begin{array}{c}\text { Ulcers at } \\
\text { week 16 }\end{array}$ \\
\cline { 2 - 4 } 1 & 9 & 12 & 16 & \\
2 & 30 & 35 & 35 & \\
3 & 29 & 39 & 39 & \\
4 & 12 & 25 & 29 & \\
5 & 2 & 13 & 19 & \\
6 & 22 & 3 & 18 & \\
10 & 6 & 21 & 29 & \\
12 & 30 & 37 & 35 & \\
7 & 10 & 23 & 13 & + \\
8 & 25 & 28 & 12 & + \\
9 & 32 & 34 & 13 & + \\
11 & 26 & 29 & 17 & + \\
13 & 29 & 29 & 26 & + \\
14 & 23 & 32 & 37 & + \\
15 & 21 & 22 & 10 & + \\
\hline \hline
\end{tabular}

${ }^{a}$ Ulcers started to appear at week 13. 
Table IV: Female Swiss mouse two-step skin carcinogenesis bioassay. Experiment 2, positive control group (G7, DMBA+TPA) - Association between ulcer development and number of gross skin papillary tumors per mouse from week 9 to $16^{*}$.

$\begin{array}{cc}\text { Ulcer-bearing } & \text { "Non-ulcer"-bearing } \\ \text { animals }(\mathrm{n}=8)^{\mathrm{a}} & \text { animals }(\mathrm{n}=7)\end{array} \quad p$ value $^{\mathrm{b}}$

Variation (\%) of the

number of papillary tumors per mouse

- $34.6(-52.3 ; 30.0) \quad 102.6(21.2 ; 381.2) \quad 0.008$

between weeks 9 and 16

Variation $(\%)$ of the number of papillary tumors per mouse - $43.7(-57.1 ;-10.3) \quad 14.2(0.0 ; 44.3) \quad 0.005$ between weeks 12 and 16

*Data is expressed in median and interquartile range. ${ }^{a}$ Ulcers started to appear at week 13.

${ }^{\mathrm{b}}$ Mann-Whitney test for independent samples. 
Table V: Female Swiss mouse two-step skin carcinogenesis bioassay. Experiment 1 association between ulcer development and incidences $(\%)$ of carcinomas per group.

\begin{tabular}{|c|c|c|c|c|}
\hline Group & Treatment & $\begin{array}{l}\mathrm{N}^{\circ} \text { of carcinomas in } \\
\text { ulcer-bearing } \\
\text { animals }(\%)\end{array}$ & $\begin{array}{c}\mathrm{N}^{\circ} \text { of carcinomas in } \\
\text { "non-ulcer"-bearing } \\
\text { animals }(\%)\end{array}$ & $p$ value $^{\mathrm{a}}$ \\
\hline G1 & $\begin{array}{l}\text { Untreated control } \\
\qquad(\mathrm{n}=18)\end{array}$ & $0 / 0(0)$ & $0 / 18(0)$ & - \\
\hline $\mathrm{G} 2$ & $\begin{array}{c}\mathrm{DMBA}+\mathrm{TPA} \\
(\mathrm{n}=15)\end{array}$ & $5 / 9(56)$ & $0 / 6(0)$ & 0.044 \\
\hline G3 & $\begin{array}{l}\text { Acetone + TPA } \\
\quad(n=17)\end{array}$ & $3 / 6(50)$ & $0 / 11(0)$ & 0.029 \\
\hline G4 & $\begin{array}{l}\text { diuron/DMSO + acetone } \\
\qquad(\mathrm{n}=19)\end{array}$ & $0 / 2(0)$ & $0 / 17(0)$ & 1.0 \\
\hline G5 & $\begin{array}{c}\text { diuron/DMSO }+ \text { TPA } \\
(\mathrm{n}=18)\end{array}$ & $6 / 8(75)$ & $0 / 10(0)$ & 0.002 \\
\hline G6 & $\begin{array}{c}\mathrm{DMBA}+\text { diuron/DMSO } \\
(\mathrm{n}=20)\end{array}$ & $0 / 0(0)$ & $0 / 20(0)$ & - \\
\hline
\end{tabular}

${ }^{\mathrm{a}}$ Fisher's Exact Test. 
Table VI: Female Swiss mouse two-step skin carcinogenesis bioassay. Experiment 2 Association between ulcer development and incidences (\%) of carcinomas per group.

\begin{tabular}{ccccc} 
Group & Treatment & $\begin{array}{c}\mathrm{N}^{\circ} \text { of carcinomas in } \\
\text { ulcer-bearing } \\
\text { animals (\%) }\end{array}$ & $\begin{array}{c}\mathrm{N}^{\circ} \text { of carcinomas in } \\
\text { "non-ulcer"-bearing } \\
\text { animals (\%) }\end{array}$ & $p$ value $^{\mathrm{a}}$ \\
\hline G7 & $\begin{array}{c}\text { DMBA + TPA } \\
(\mathrm{n}=15)\end{array}$ & $5 / 12(42)$ & $1 / 3(33)$ & 1.0 \\
G8 & $\begin{array}{c}\text { diuron/acetone + TPA } \\
(\mathrm{n}=15)\end{array}$ & $6 / 10(60)$ & $0 / 5(0)$ & 0.044 \\
G9 & $\begin{array}{c}\text { diuron/DMSO + TPA } \\
(\mathrm{n}=14)\end{array}$ & $6 / 10(60)$ & $0 / 4(0)$ & 0.085 \\
\hline \hline
\end{tabular}

${ }^{\mathrm{a}}$ Fisher's Exact Test. 


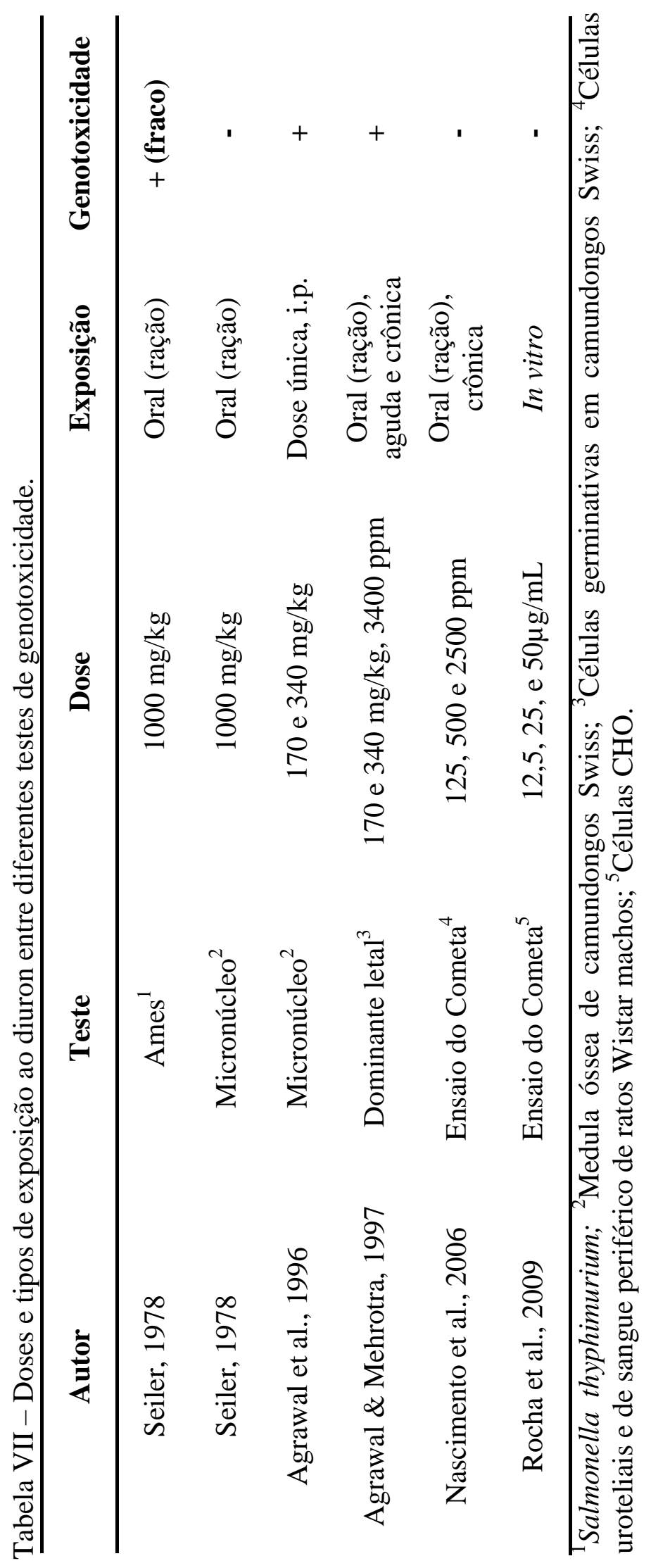




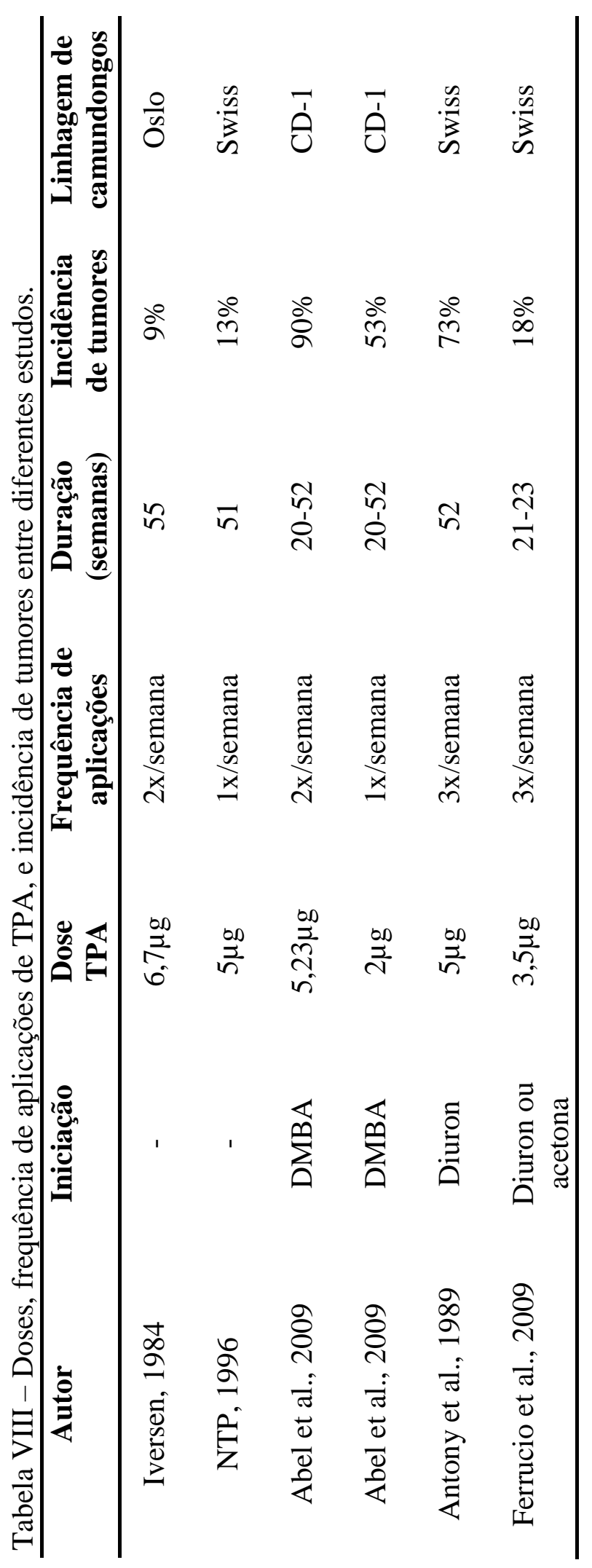




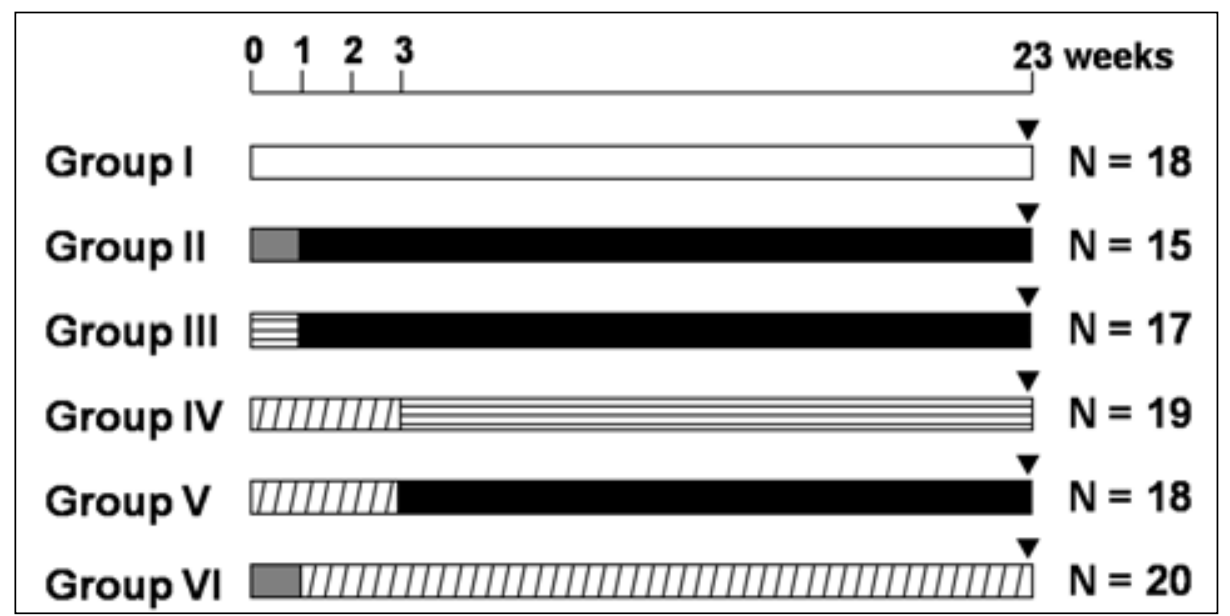

Figure 1 - Experimental design 1

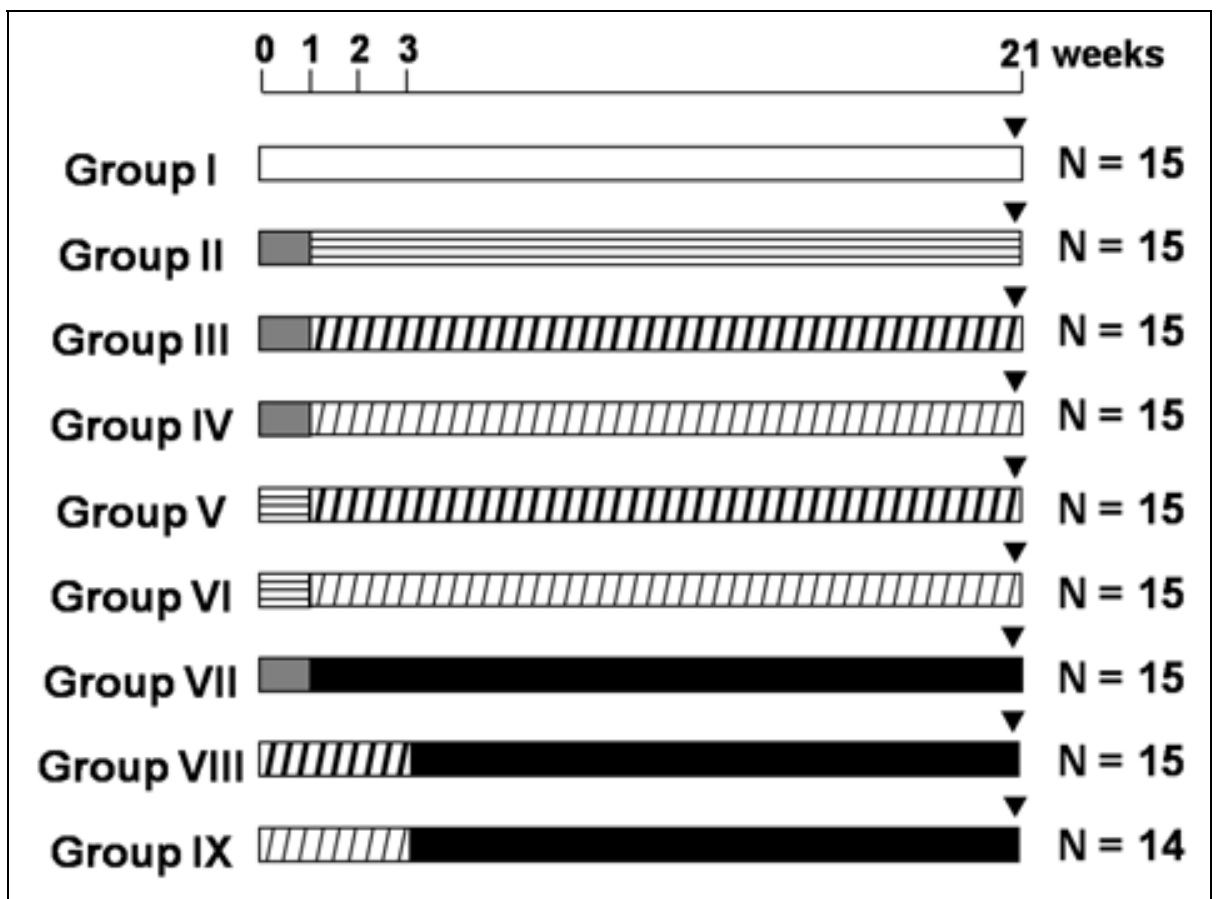

Figure 2 - Experimental design 2

Untreated control

DMBA $52 \mu \mathrm{g} / 100 \mu \mathrm{L}$ acetone (single application)

$\square \quad$ TPA $3.5 \mu \mathrm{g} / 100 \mu \mathrm{L}$ acetone (3 applications/week)

目 $100 \mu \mathrm{L}$ acetone (3 applications/week)

(7) Diuron $250 \mathrm{mg} / \mathrm{Kg}$ b.w. diluted in $100 \mu \mathrm{L}$ DMSO (3 applications/week)

W Diuron $250 \mathrm{mg} / \mathrm{Kg}$ b.w. diluted in $100 \mu \mathrm{L}$ acetone (3 applications/week) 
$\nabla$ Euthanasia

$\mathrm{N}=$ Number of animals at the end of the experiment

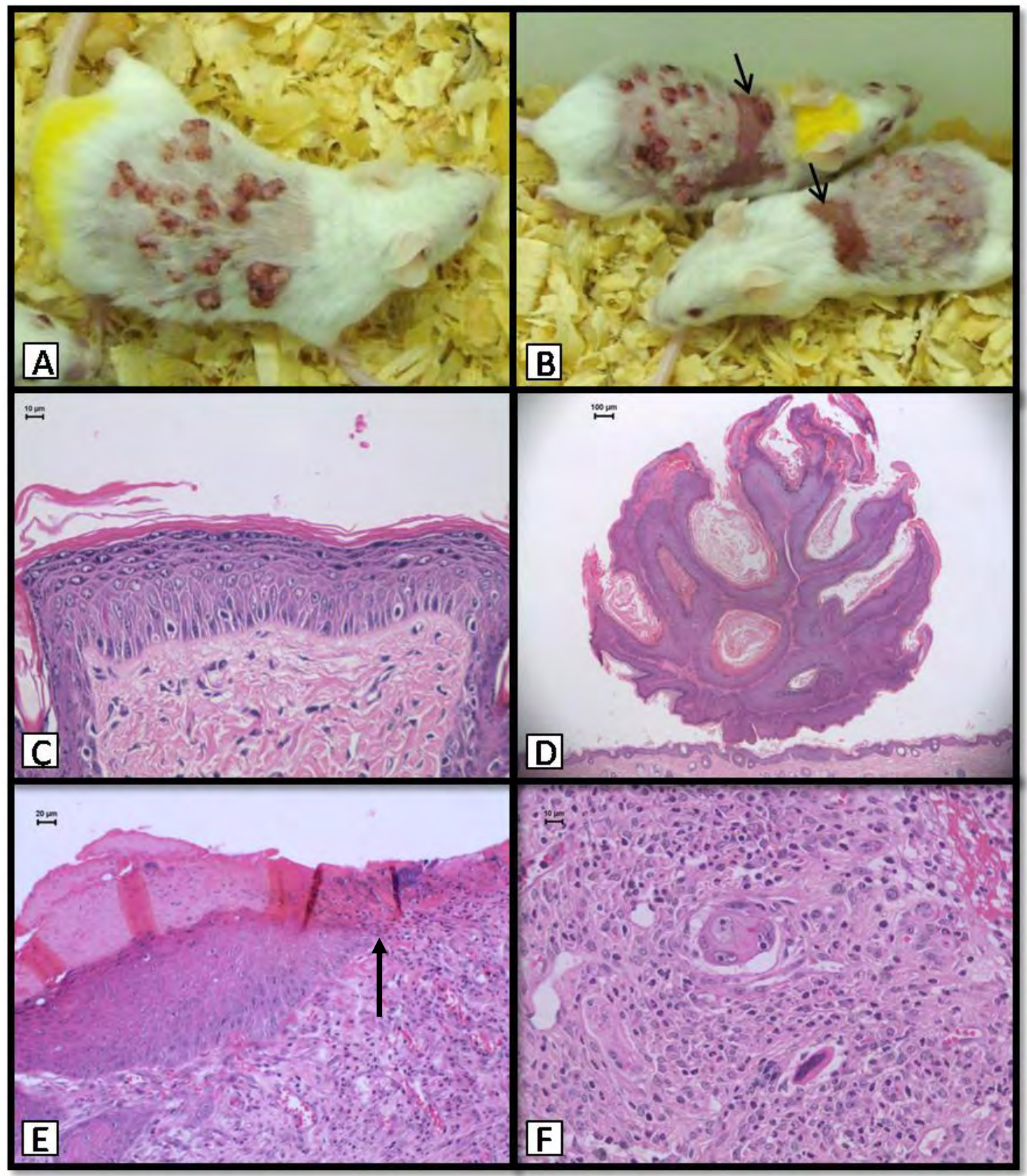

Figure 3 - TPA-treated animals. Macroscopic lesions: A, B) Papillomas and ulcers (arrows). Histological lesions: C) Accentuated epidermal hyperplasia; D) Papilloma; E) Acanthosis and paraceratosis at the ulcer border (arrow at the limit); F) Squamous cell carcinoma infiltrating granulation tissue at the ulcer bottom. 